\title{
Strategic actions for local tourism development in the municipality of San Juan de los Remedios, Cuba
}

\section{Acciones estratégicas para el desarrollo turístico local del municipio San Juan de los Remedios, Cuba}

1 Juan Ernesto Gutiérrez Leyva

Profesor Instructor, Facultad de Turismo de la Universidad de La Habana. Cuba

2 Miguel Ángel Espinosa Cuarta

Estudiante de Pregrado, Facultad de Turismo de la Universidad de La Habana. Cuba

3 Yudemir Cruz Pérez

Profesor Titular, Facultad de Turismo de la Universidad de La Habana. Cuba

4 Luis Efraín Velastegui López $\quad$ (iD) https://orcid.org0000-0002-7353-5853

Universidad Técnica de Babahoyo, Babahoyo, Ecuador

evelasteguil@utb.edu.ec

Artículo de Investigación Científica y Tecnológica

Enviado: 07/12/2021

Revisado: $19 / 12 / 2021$

Aceptado: 29/01/2022

Publicado:08/03/2022

DOI: https://doi.org/10.33262/exploradordigital.v6i1.2092

Cítese:

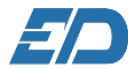

Ciencia

Digital

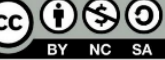

Gutiérrez Leyva, J. E., Espinosa Cuarta , M. Ángel, Cruz Pérez, Y., \& Velastegui López, L. E. (2022). Strategic actions for local tourism development in the municipality of San Juan de los Remedios, Cuba. Explorador Digital, 6(1), 75-89. https://doi.org/10.33262/exploradordigital.v6i1.2092

EXPLORADOR DIGITAL, es una Revista electrónica, Trimestral, que se publicará en soporte electrónico tiene como misión contribuir a la formación de profesionales competentes con visión humanística y crítica que sean capaces de exponer sus resultados investigativos y científicos en la misma medida que se promueva mediante su intervención cambios positivos en la sociedad. https://exploradordigital.org

La revista es editada por la Editorial Ciencia Digital (Editorial de prestigio registrada en la Cámara

Ecuatoriana de Libro con No de Afiliación 663) www.celibro.org.ec 


Palabras claves:
acciones
estratégicas
gestión, San Juan
de los Remedios,
gestión turística,
desarrollo turístico
local.

\section{Keywords:}

strategic actions management, San Juan de los Remedios, tourist management, local tourist development.

\begin{abstract}
Resumen
El propósito del trabajo fue determinar las acciones estratégicas necesarias para el desarrollo turístico local del municipio San Juan de los Remedios, Cuba; para lo cual se desarrollaron tres etapas de investigación: la fundamentación del marco teórico de la gestión turística en ciudades patrimoniales, la caracterización de la actividad turística en Remedios y sus potencialidades y finalmente la formulación de acciones estratégicas en correspondencia para el desarrollo turístico local desde una perspectiva integral y sostenible. De la investigación resultó que el producto turístico territorial en cuestión debe aplicar estrategias de supervivencia para afrontar las amenazas del entorno y debilidades previamente identificadas mediante consultas a especialistas y Talleres de Acción y Participación. En base a las principales variables detectadas en una lista ponderada y su influencia en el desarrollo turístico local se determinó aplicar una estrategia de diferenciación; proponiendo acciones enmarcadas a identificar las necesidades del segmento que demanda este producto y aprovechar las individualidades que hacen de la "Ciudad de Aldabas y Faroles" un tesoro histórico cultural singular dentro del Caribe.
\end{abstract}

\section{Abstract}

The purpose of the work was to determine the strategic actions necessary for the local tourism development of the San Juan de los Remedios municipality, Cuba; For which three research stages were developed: the foundation of the theoretical framework of tourism management in heritage cities, the characterization of the tourist activity in Remedios and its potentialities and finally the formulation of strategic actions in correspondence for the local tourism development from a comprehensive and sustainable perspective. The investigation showed that the territorial tourism product in question must apply survival strategies to face the threats of the environment and previously identified weaknesses through consultations with specialists and Action and Participation Workshops. Based on the main variables detected in a weighted list and their influence on local tourism development, it was determined to apply a differentiation strategy; proposing actions framed to identify the needs of the segment that demands this product and take 
advantage of the individualities that make the "City of Knockers and Lanterns" a unique cultural historical treasure within the Caribbean.

\section{Introduction}

Tourism is one of the most important economic sectors worldwide. With a remarkable growth every year, the travel sector proves to be a viable solution to achieve a greater economic development of the communities that host this activity.

According to data from the World Tourism Organization (UNWTO, 2020), international tourism represents around $7.5 \%$ of world exports, since it has had, from 2012 to this date (makes an analysis from 2014 to 2018 so it does not register the Covid 19 pandemic affectations), a growth higher than that of world trade. Pololikashvili (2019), current Secretary General of the UNWTO, states that in 2018 alone, the figure of 1.4 billion tourist arrivals was reached, which represented an increase of 5\% compared to the previous year.

In this sense Pololikashvili (2020), indicates the need for responsible growth in the sector, ensuring that there is no division between sustainable and unsustainable tourism. Sustainability is not an add-on but a cross-cutting value that must be incorporated into all stages of tourism development. This refers to the social, cultural, economic and environmental dimension, the effectiveness of the destination management organization (DMO), minimizing the negative impacts in the host communities and maximizing the economic, spiritual and cultural benefits of this activity.

Richards (2018), outlines that the rise of culture and traditions within tourism is currently notable thanks to the change in tourism behavior models, which takes place in the substitution of escapism for enrichment, this occurs, in the gradual depletion of traditional sun and beach tourism, in the face of the development of a segmented and demanding tourism that increasingly values aspects related to culture, historical heritage, the environment and the discovery of new sites.

Salinas \& Salinas (2019), highlight the development that tourism activity has gradually been reaching in Cuba, depending on the potential of natural resources and the historicalcultural characteristics of the country, they have made it an important sphere of the economy, both for be a source of foreign exchange income, as well as its possibilities to boost other activities of the national economy, always supported by the policy of sustainable development 
García (2021), Minister of Tourism of Cuba emphasizes the joint work developed by the Ministries of Culture and Tourism, the National Union of Writers and Artists of Cuba (UNEAC) and the National Trade Unions of Culture and Tourism, as well as the active participation of prominent creators has been of importance for the promotion of Cuba as an especially cultural tourist destination.

The heritage cities of Cuba play a fundamental role in the country's strategy to revitalize tourism as one of the main lines of the national economy, proposing the visitor to enjoy all the historical and traditional roots that they treasure, such as Havana, Trinidad, Morón, Holguín, Santiago de Cuba and Remedios; the latter becomes the object of study of this research.

Despite the strengths that the territory possesses, the studies prepared from theoreticalmethodological tools are still considered insufficient or non-existent, which allow the use of the potentialities offered by the municipality as a fundamental gear in the social and economic local improvement. Therefore, it is necessary to develop adequate tourism development planning in the Remedial territory, so that it holds its rightful place as one of the main places to visit in Cuba. For the authorities of the territory, the studies or proposals for strategic actions for the development of new products are of an individual nature and do not have a territorial dimension.

\section{Methodology}

The work was based on three fundamental stages, fundamentation, characterization and formulation of actions, whom are presented in table 1. During the investigation, consultation with specialists prevailed, and the weighting and evaluation of specialized criteria in Participation Action Groups.

From the theoretical level (through the procedures of analysis and synthesis, abstraction and integration, and induction and deduction): historical or trend method and logical methods (dialectical, systemic structural - functional and hypothetical - deductive).

From the empirical level: Survey method: Interview: the non-structural type was applied in depth to the key actors of tourism management in the area, during the diagnosis of the tourism offer. For its preparation, a preliminary test was carried out that facilitated correcting the objective and the questions asked, as well as greater efficiency in its preparation and application.

Scientific observation: it was developed through the application of the qualitative technique of the Focus Group, this was carried out with a Traditional Focus Group where the key actors available in the tourist area participated; and an Online Focus Group with key players not available in the area. 
Between both groups, the main demand segments for cultural tourism in the area were characterized. Systems analysis techniques: through the analytical conglomerate of Fontalvo (De la Hoz, 2018).

Table 1

Research Stages

\begin{tabular}{|c|c|}
\hline Objectives & Stages of research \\
\hline $\begin{array}{l}\text { - Establish the theoretical approaches of destination } \\
\text { management organization in heritage cities. }\end{array}$ & $\begin{array}{l}1^{\text {st }} \text { stage: } \\
\text { Review of the theoretical and conceptual } \\
\text { framework on DMO. }\end{array}$ \\
\hline $\begin{array}{l}\text { - Characterize tourism activity in Remedios through } \\
\text { determining key internal and external factors using the } \\
\text { SWOT matrix. } \\
\text { - Identify and propose strategies. }\end{array}$ & $\begin{array}{l}2^{\text {nd }} \text { stage: } \\
\text { Characterization and determinations of Key } \\
\text { Factors. } \\
3^{\text {rd }} \text { stage: } \\
\text { Strategy development }\end{array}$ \\
\hline
\end{tabular}

\section{Results}

\section{Diagnosis of the tourist situation of the territory}

As a primary reference for the situational analysis of tourism development, the internal and external analysis of local tourism development was carried out. To carry out the external analysis, the macroenvironment and microenvironment were studied, for which the PESTEL tool and the analysis of the 5 competitive forces by Michael Porter respectively were used. The diagnosis derived from a field work in two moments: obtaining verified information and interviews.

\section{Macro environment analysis}

According to Martín (2006), the macro environment is a set of national, international or global factors or processes that, although they do not directly affect the operation of the destination, set important guidelines and influences on it and on its subsequent development. The political-legal, economic, socio-cultural, technological and environmental environments are considered (PESTLE analysis), which configure the global position of the social environment where the performance of the destination management is framed.

Legal political environment: national policy: Cuba fully guarantees the political and monetary stability of the country; In addition, there is a government political will to promote tourism, mitigating negative impacts that may exist in society, using the national culture in a prominent way.

International politics: Cuba does not remain aside from issues as globalization, but it is good to point out that it is not influenced by the economic policies of the IMF 
(International Monetary Fund) and the World Bank. Prestigious foreign companies participate in Cuban tourism development, but the State is always the main shareholder in the various projects and associations. The country has been highly affected by the health crisis that is currently affecting the world economy, most of all, those sectors associated to travel.

Due to the health crisis of COVID-19 that is affecting the world, seclusion policies have been promoted, preventing the mobility of people for contagious reasons. This constitutes a representative blow to the tourism sector and to the confidence of potential tourists. The campaign developed by international organizations such as ICOMOS has been a great support in the protection and safeguarding of the historical cultural heritage of humanity. This body, with the auspices and defense consolidated by UNESCO, has been developing, since 1964, an enormous professional work in the drafting of International Letters that cover all the artistic and cultural expressions of humanity, which serve as guidelines for the management of heritage cities; in line with the growth of tourists' interest in knowing this vast spiritual treasure that these destinations keep.

Economic: Presence of an economic-financial crisis that affects all countries and sectors of the economy, which has been accentuated by the spread of COVID-19 (World Bank, 2020). Usual features such as constant renewal of products and services, displacement of manufacturing activities to the production of services, globalization of markets, increased preference for quality, increased mergers and alliances between companies at an international level.

On the other hand, the economic blockade also has a great repercussion on tourism activity in a very significant way. In the first place, because the bulk of the imported products that are necessary for the development of the extra-hotel activity come from Asia and Europe, which implies a rise in prices and transportation costs. The economic process is conditioned by the preeminence and regulatory role of the state sector, the execution of the Business Improvement process; the generalized application of information technology and the negotiation with foreign capital conditioning the multiplication of other branches of the economy.

Sociocultural: Cuba has a high educational, cultural and health level, social and political stability and accepted standards of living. It is intended to raise the training and development of human resources working in tourism, as well as the tourist culture of the population. Cuban people are aware on the basis of the environmental culture of the entire town and university students have acquired a high environmental consciousness, becoming increasingly interested in ecological projects, as they understand the urgency of the issue. For its part, the country has worldwide prestige for healthy tourism that combines leisure with activities that help improve the quality of life. Even being a country 
that is on ways of development, Cuba has one of the first places on indicators such as health and social care (Mas, 2021).

Technological: The Internet has transformed the traditional configuration of the distribution chain and the promotion channels for its products. Its use has generated different solutions that optimize this distribution chain, such as the large Global Distribution Systems (GDS) and the Central Reservation Systems (CRS), forcing companies to enter a new world, where the use of technology is decisive.

Thanks to the development of the network infrastructure and access facilities that the country currently has, it has been possible to establish a greater number of WIFI zones throughout the country and the connection by mobile data that varies from $2 \mathrm{G}$ to $4 \mathrm{G}$. Similarly, social networks are currently the main marketing channels, due to the constant increase in Computerization and Communication Technologies (ICT). The lack of airport buildings represents a complication for accessibility to Remedios, the international airport being located in the city of Santa Clara, more than 50 kilometers from these cities.

Environmental Situation: As Remedios is a heritage city, its main strength lies in the immense heritage value of the colonial city, without having a great presence of natural attractions that could attract demand by themselves. In the same way, the tourist uses of the potential that San Juan de los Remedios offers inevitably implies negative impacts on the ecosystems where it takes place.

The urban environmental problem in which tourism is expanding is characterized by technical inadequacies, such as the sewerage solutions in the historic center of the city, the deficient aqueduct network, deficit of parking areas, lack of a public lighting system and the electrical layout that affects the urban image. The state of deterioration of the settlement also affects, in which there are great effects on the housing fund of the city and their conditions, as well as the problem of urban waste treatment. In general, many of these problems are reinforced by the lack of environmental and tourist culture of the local population. In addition, the town of San Juan de los Remedios lacks from green areas and natural spaces that could enhance the attractiveness of the city.

In Remedios, physical, cultural and historical elements are ideally integrated for the development of multiple tourist modalities, in addition to the immense tourist value that the old city has, it is worth highlighting its proximity to other areas of great attraction where there are benefits that can be easily used for the development of tourist activity: excellent climate, beautiful beaches in the northern keys and mountainous areas, with a great wealth of flora and fauna, which can be combined through short trips and excursions to these areas. 


\section{Micro environment analysis}

From the point of view of Porter (1980), the capacity of an enterprise to compete in a specific market is determined by its technical and economic resources, as well as by environmental forces, each of which threatens the entrance of the organization in a new market. In this way, the analysis of these forces becomes vital for any company, which are:

- Rivalry among existing competitors

- Threat of new entrants.

- Threat of Substitute products.

- Bargaining power of buyers.

- Bargaining power of suppliers.

Rivalry among existing competitors: conforming to Serra (2002), a destination rarely acts only in one market, but rather has to coexist or face a whole series of competitors. For Cardet (2016), knowledge of the competence is an essential aspect for making decisions, since in this way the advantages and disadvantages will be identified, and strategies will be drawn accordingly. In Cuba, in addition to Remedios, other heritage cities of great importance proliferate, ready to offer similar and better-quality services. Among them, the Historic Center of Havana stands out, which, declared as world heritage in 1981, constitutes one of the main destinations of this type in the nation.

Trinidad stands another threat to the tourist development of Remedios, especially due to its proximity and its diversified tourist offer, the Trinidadian city is one of the main tourist destinations in the Cuban nation. Faced with the prominence of these destinations, San Juan de los Remedios combines leading elements of Cuban cultural heritage, in addition to that, due to its closeness and easy accessibility to other destinations, including Caibarién, La Hanabanilla and the northern keys of Las Villas, tourism managers at the destination could develop excursion offers that allow the practice of modalities such as those related to the Sun and the beach and nature.

Threat of new entrants: Serra (2002), states that a segment is not attractive if it is very likely to attract new competitors who will increase the capacity offered. Added to this is the possibility that there are conditions that make it difficult for these competitors to exit the market, which would further increase the risk. That is why the attractiveness of each segment varies depending on the barriers to entry and exit the market. Pointing out the existence of 4 different scenarios.

- High entry and exit barriers: High profitability and risk.

- High entry barriers and low exit barriers: High and stable profitability.

- Low entry barriers and low exit barriers: Low and stable profitability. 
- Low entry barriers and high exit barriers: Low profitability and risk.

This segment is in the second scenario, which gives a favorable situation to the tourism product in question. The high entry barriers are due in large part to the rigid environmental policies that regulate the development of tourist activities in these types of destinations, in order to protect them from a carrying capacity that may cause permanent damage.

Threat of substitute products: In the country there are several destinations that offer similar products, among them it is necessary to highlight heritage cities of interest such as Havana, Trinidad and Santiago de Cuba; However, the Remedian city is characterized by the uniqueness of its cultural values; those that differentiate it from the rest of the destinations.

Bargaining power of buyers: Other territorial tourism products with similar characteristics are offered in the country. This, added to the increasingly high demands of the market that demands these products, give the buyer a certain power over the offer.

Bargaining power of suppliers: In this sense, it should be emphasized that there are not many providers available, which are concentrated and belong to government institutions mostly. This often causes inputs to be limited by national and international policies that affect the importation of these types of products into the country, as well as their national production. Similarly, the main attraction is made up of the heritage value of the city.

An external analysis of the municipality was carried out and the weighted List of Threats and Opportunities was obtained. It was based on the recognition of the recent insertion of tourism as a social phenomenon in the context of this city with potential for tourist use, but without prior experiences with respect to tourism and with a previous structural base oriented to other social and economic activities. The lists were presented as following:

Weighted list of threats for DMO

1. World economic instability that affects the main source markets.

2. Global health crisis of Covid-19.

3. Strong concentration at the national level of the supply-demand of this tourist product in the historic urban center of Havana.

4. Increase in tourism promotion and marketing campaigns for other consolidated cultural destinations.

5. Increasingly high expectations of the market segment that demands this product.

6. Location of the international airport in the city of Santa Clara, more than 50 kilometers from these cities.

7. Relative proximity of the Historic City of Trinidad, also in the central part of Cuba, as a well-positioned alternative for the development of tourist programs. 
8. Loss of confidence of tourists when traveling due to the health crisis of COVID19.

\section{Weighted list of opportunities for DMO}

1. Positioning of the cultural tourism segment as a growing modality for experiential learning of the history and culture of the peoples.

2. Promotion of general and comprehensive education in Cuba with better levels of training.

3. Campaigns for conservation and respect for cultural heritage by UNESCO and ICOMOS.

4. Recovery of the tourist attractiveness of the historical-cultural cities.

5. Proximity to the tourist destination "Cayos de Villa Clara", where major hotel chains operate under the Playa Plus concept interested in promoting visits to the city.

6. Advantageous position with respect to the Central University of Las Villas, the School of Hospitality and Tourism, as well as important research centers.

7. Promotion of national tourism development, as well as the implementation of policies for the diversification of the Cuban tourism product and the complementary offer to the sun and beach product.

8. Location in one of the eight prioritized regions for tourism development in the country.

\section{Internal analysis}

San Juan de los Remedios has dissimilar resources and attractions capable of attracting tourist flows. The local population is highly involved in the development of tourist activity, generating positive impacts in the complementation and diversification of the offer, together with the local authorities in charge of the DMO. Remedios is also one of the main sources of tourist entry into Las Villas area, along with the northern keys of this region, presenting itself as a natural proposal for the development of alternative tourism other than the mass of sun and beach tourism that usually characterizes this area. These conditions make Remedios identifiable in a "Development" phase of its life cycle (Butler, 1980).

Through group work sessions with the participants in the different training activities carried out, the internal analysis of local tourism development was carried out and the Weighted List of Strengths and Weaknesses was obtained. It was prepared in a participatory way according to social perception of the impacts of tourism for the local host community. 
Weighted list of weaknesses for DMO

1. Poor preparation of the destination managers for the tourist enhancement of the tangible and intangible cultural heritage.

2. Insufficient general tourist culture in the local population.

3. Lack of informational material to support destination management.

4. Insufficient capacity for tourist hotel accommodation and a limited supply of restaurants and specialized services.

5. Deficit of technical and support infrastructure.

6. Peripheral neighborhoods with environments of low aesthetic value close to the area of tourist use.

7. Deficit of open spaces and green areas surrounding the urban center.

8. Tourist underutilization of the historical-cultural heritage.

Weighted list of strengths for DMO

1. High potential and conservative status of the historical cultural heritage, both the built heritage and the intangible heritage.

2. Progressive social appreciation of tourist activity as a basic component of the city's economy.

3. Declaration of the city of Remedios as a "National Monument" since 1980.

4. Good accessibility in the regional territorial framework.

5. Existence of a strong sense of identity and belonging on the part of the local inhabitants.

6. Development of non-hotel tourist accommodation in private homes.

7. They are tourism products that generate jobs in the areas where they are located.

8. Human capital committed to the preservation of heritage.

From the weighted list of threats, opportunities, strengths and weaknesses, a SWOT matrix (table 2) was made to verify the impact of the variables and develop a generic strategy accordingly.

\section{Strategy development}

The strategy development process is presented analytically by using the SWOT Matrix presented in table 2. The municipality of San Juan de los Remedios was selected as case of study. Expert groups were determined, mostly conformed by tourism managers such as hotel managers, representants from renown and experienced travel agencies in the marketing of heritage cities and academics. 
Table 2

SWOT Matrix

\begin{tabular}{|c|c|c|c|c|c|c|c|c|c|c|c|c|c|c|c|c|c|c|}
\hline & O1 & $\mathrm{O} 2$ & O3 & $\mathrm{O} 4$ & O5 & O6 & O7 & O8 & & A1 & A2 & A3 & A4 & A5 & A6 & A7 & A8 & \\
\hline F1 & 3 & 1 & 3 & 3 & 2 & 2 & 3 & 3 & & 1 & 1 & 3 & 2 & 3 & 1 & 2 & 3 & \\
\hline F2 & 3 & 2 & 2 & 3 & 3 & 2 & 2 & 3 & & 1 & 1 & 2 & 2 & 2 & 1 & 2 & 1 & \\
\hline F3 & 3 & 1 & 3 & 3 & 2 & 1 & 2 & 3 & & 1 & 1 & 3 & 3 & 3 & 1 & 2 & 2 & \\
\hline F4 & 1 & 1 & 1 & 1 & 3 & 1 & 1 & 1 & & 1 & 1 & 1 & 1 & 1 & 3 & 1 & 1 & \\
\hline F5 & 3 & 1 & 3 & 3 & 1 & 1 & 2 & 1 & & 1 & 1 & 1 & 1 & 1 & 1 & 1 & 3 & \\
\hline F6 & 2 & 1 & 1 & 2 & 1 & 1 & 3 & 2 & & 1 & 1 & 1 & 1 & 1 & 1 & 1 & 1 & \\
\hline F7 & 2 & 3 & 2 & 2 & 3 & 2 & 2 & 3 & & 1 & 1 & 1 & 1 & 1 & 1 & 1 & 1 & \\
\hline \multirow[t]{2}{*}{ F8 } & 3 & 2 & 3 & 3 & 2 & 1 & 2 & 2 & & 1 & 1 & 1 & 1 & 2 & 1 & 1 & 3 & \\
\hline & & & & & & & & & 133 & & & & & & & & & 91 \\
\hline D1 & 3 & 1 & 2 & 3 & 3 & 1 & 3 & 3 & & 2 & 3 & 3 & 3 & 3 & 1 & 3 & 3 & \\
\hline D2 & 3 & 1 & 1 & 3 & 3 & 1 & 3 & 3 & & 2 & 3 & 2 & 2 & 2 & 1 & 3 & 2 & \\
\hline D3 & 3 & 1 & 2 & 3 & 3 & 1 & 3 & 3 & & 3 & 3 & 2 & 3 & 3 & 1 & 3 & 3 & \\
\hline D4 & 3 & 1 & 1 & 2 & 1 & 1 & 3 & 3 & & 2 & 3 & 2 & 2 & 2 & 1 & 3 & 3 & \\
\hline D5 & 3 & 1 & 2 & 3 & 2 & 1 & 3 & 3 & & 3 & 3 & 2 & 2 & 3 & 2 & 2 & 3 & \\
\hline D6 & 3 & 1 & 3 & 2 & 1 & 1 & 3 & 3 & & 2 & 3 & 2 & 2 & 3 & 1 & 2 & 1 & \\
\hline D7 & 1 & 1 & 2 & 2 & 1 & 1 & 2 & 2 & & 1 & 3 & 2 & 2 & 2 & 1 & 2 & 3 & \\
\hline \multirow[t]{2}{*}{ D8 } & 3 & 1 & 2 & 3 & 2 & 1 & 3 & 3 & & 1 & 3 & 3 & 3 & 3 & 1 & 3 & 2 & \\
\hline & & & & & & & & & 136 & & & & & & & & & 148 \\
\hline
\end{tabular}

Using the SWOT Matrix, the following generic strategy was identified:

Survival strategy to face the main weaknesses and threats that affect the tourism development of the San Juan de los Remedios municipality. The answer that is offered aims to cover the insufficient tourist culture of the local population and decision makers, as well as the lack of preparation of tourism managers for the enhancement of cultural heritage, facing the threats of the environment related in the first place to the health and economic crisis rooted by the COVID-19 pandemic and to the concentration of demand for this product in the Historic Center of Havana.

Kisi (2019), proposed a strategic approach for the sustainable tourism development of touristic destinations by applying the A WOT Method and the TOWS Matrix in accordance with the region-specific vision statement and main sustainable tourism goals. In this study was used the SWOT Matrix and was identified accordingly the next regionsspecific vision statement: "To ensure long term and sustainable development of the tourism industry in the San Juan de los Remedios municipality".

In consequence, the main sustainable goals were determined: 
- Involving all actors in DMO.

- Providing better-quality services to visitors.

- Providing economic benefits for local and regional development.

- Minimizing negative environmental impacts and protecting the authenticity of the municipality.

To achieve these goals effective strategies should be implemented and taken into accountancy. According to the results thrown by the analysis of the SWOT matrix, strategies were developed:

- Take advantage of its position as a National Monument and its high conservative value to offer the client a differentiated value that meets the demanding needs and tendencies.

- Develop a marketing-oriented approach, identify the needs of the segment that demands this product and take advantage of the individualities that make Remedios a unique cultural historical treasure within the Caribbean

- Initiate effective promotion and communication campaign to regain tourist's trust.

- Diversify offers by complementing it with others with great popularity and demand in the region such as sun and beach tourism in the northern keys.

\section{Conclusions}

- The San Juan de los Remedios municipality has numerous potentialities for the development of tourist activity in the territory, standing out for being an indissoluble part of the nation's cultural historical heritage.

- By applying the cross-impact matrix, the application of survival strategies for local tourism development in Remedios was determined.

- The managers of the tourist product San Juan de los Remedios must apply a survival strategy, in order to stand ground against the weaknesses and surrounding threats.

- The destination must apply strategic actions based on the main variables identified in the SWOT Matrix, making most of its current situation in terms of benefits and liquidity. The environment is threatening, and the situation of the current DMO is poor, actions must be taken immediately to revert these affectations.

\section{References Bibliographical}

Butler, R. (1980). The concept of a tourist area cycle of evolution: Implications for the management of resources. The Canadian Geographer, 5-12.

Cardet Fernández, E. (2016). Gibara, tradición y modernidad de un municipio turístico para diversificar la oferta del destino Holguín. Turismo y Sociedad, 51-74. 
De la Hoz, Efraín. (2018). Método Combinado Análisis de Conglomerado y Análisis Discriminante Multivariado para Identificar y Evaluar Perfiles de Eficiencia Financiera en Empresas Exportadoras. Información Tecnológica, 227-234.

García, J. (8 de abril de 2021). Comisión Nacional Cultura-Turismo chequea trabajo conjunto. (D. Calderón Terry, Entrevistador)

Kisi, N. (2019). A strategic approach to sustainable tourism development using the A WOT Hybrid Method: A case of study of Zonguldak, Turkey. Sustainability.

Martín Fernández, R. (2006). Principios Organización y Práctica del Turismo. La Habana: Félix Varela.

Mas, Pedro. (2021). Equity and the Cuban National Health System's response to Covid 19. Pan American Journal of Public Health, Special report.

Pololikashvili, Z. (2019, January 21). International tourist arrivals reach 1.4 billion two years ahead of forecasts. Retrieved January 10, 2022, from UNWTO: ttps://www.unwto.org/global/press-release/2019-01-21/international-touristarrivals-reach-14-billion-two-years-ahead-forecasts

Pololikashvili, Z. (2020). UNWTO Regional Conference on sustainable development through tourism . UNWTO Regional Conference on sustainable development through tourism-Proceedings (p. 20). Bhutan: Spain.

Porter, M. (1980). Competitive Strategy: Techniques for analyzing Industries and competitors. Nueva York: Free Press.

Richards, G. (2018). Cultural Tourism: A review of recent research and trends. Academia, 12-21.

Salinas, E., \& Salinas, E. (2019). El turismo en Cuba: Desarrollo, retos y perspectivas. Redalyc, Vol. 11 No. 1.

Serra, A. (2002). Marketing turístico. Madrid: ESIC.

World Tourism Organization [UNWTO]. (2020). World Tourism Barometer 2019. World Tourism Barometer, Volume 17; Issue 4.

World Bank. (2020). The potential impact of Covid 19 on GDP and trade. East Asia and the Pacific Region: Own edition.

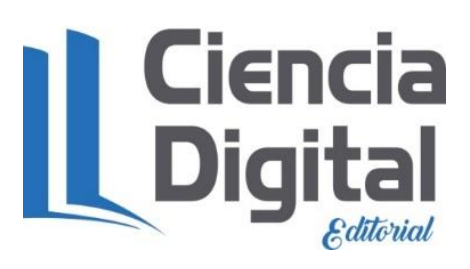


El artículo que se publica es de exclusiva responsabilidad de los autores y no necesariamente reflejan el pensamiento de la Revista Explorador Digital.

\section{Ciencia \\ LDigital}

El artículo queda en propiedad de la revista y, por tanto, su publicación parcial y/o total en otro medio tiene que ser autorizado por el director de la Revista Explorador Digital.
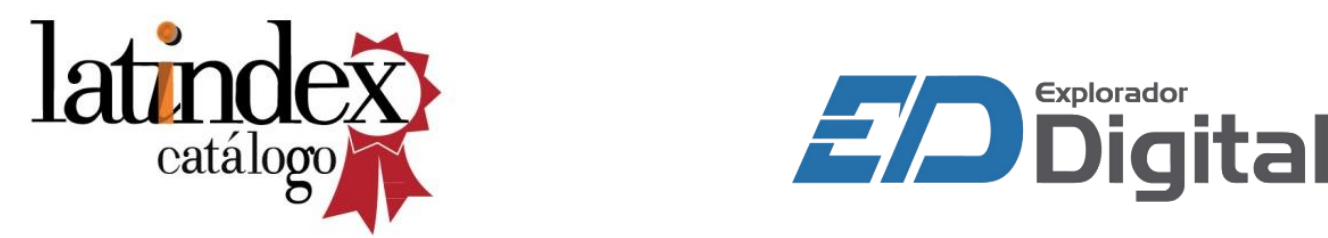

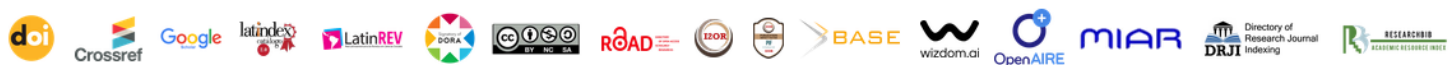
ERTHPLU औitefactor 